LOCAL WISDOM, 9 (1): 118-130, 2017
Local Wisdom Scientific Online Journal
ISSN: 2086-3764

\title{
PENGARUH KEARIFAN BUDAYA LOKAL TERHADAP HUNIAN MASYARAKAT PENGRAJIN TEMPE DI KAMPUNG SANAN MALANG
}

\author{
Rahadian Nugroho \\ 166060500111008 \\ nugroho.rahadian@yahoo.com
}

\begin{tabular}{|c|c|}
\hline & Abstrak \\
\hline $\begin{array}{l}\text { Kata Kunci: } \\
\text { Kearifan Lokal, } \\
\text { Ekonomi, } \\
\text { Kerajinan Tempe, } \\
\text { Tradisi Budaya, } \\
\text { Sanan Malang }\end{array}$ & $\begin{array}{l}\text { Hunian masyarakat pengrajin tempe di Kampung Sanan Malang merupakan hunian yang } \\
\text { terbentuk dari penyesuaian kearifan lokal yang lama tehadap globalisasi yang salah satunya } \\
\text { berdampak ke ekonomi. Pada awalnya, huniandi kampungini hanya digunakan untuk tempat } \\
\text { tinggal, namun kemudian pendudukmulai menggunakanhunian mereka untuk memproduksi } \\
\text { serta menjual tempe dan keripik tempe, dan saat ini Kampung Sanan telah menjadi sentra } \\
\text { industri tempe. Kegiatan memproduksi tempe bagi masyarakat Kampung Sanan merupakan } \\
\text { Kearifan Budaya Lokal turun-temurun yang memungkinkan terjadinya perubahan dan } \\
\text { pengurangan pada ruang untuk tempat tinggal serta mempengaruhi kualitas fasad hunian. } \\
\text { Studi ini bertujuan untuk mendeskripsikan konsep kearifan lokal dalam pola hunian } \\
\text { masyarakat kampung Sanan Malang yang berpengaruh pada perubahan-perubahannya. } \\
\text { Metode yang digunakan dalam studi ini adalah deskriptif, analitis dan interpretatif berdasar } \\
\text { pada bukti empiris, strukturalisme, tipolmorfo dan relasi fungsi, bentuk dan makna yang } \\
\text { digunakan untuk mengungkap konsep kearifan lokal dalam hunian masyarakat kampung } \\
\text { Sanan Malang. Pengumpulan datanya dilakukan dengan pengambilan foto, video, wawancara } \\
\text { mendalam dan observasi kemudiandianalisis untuk mendapatkan gambaran dan kesimpulan } \\
\text { yang dapat menjawab permasalahan dan mencapai tujuan studi. Hasil dari studi ini } \\
\text { menyebutkan bahwa kearifan budaya lokal Kampung Sanan secara langsung dan tak langsung } \\
\text { memunculkan identitas dan tradisi baru yang berjalan beriringan dengan tradisi yanglama. } \\
\text { Terbentuknya kearifan budaya lokal yang baru dari dampak globalisasi yaitu Home Industry } \\
\text { karena untuk menaikkan taraf hidup warga Kampung Sanan Malang. }\end{array}$ \\
\hline
\end{tabular}

Keywords:

Local Wisdom, Residential Changes, Tempe Craftsmen, Cultural Tradition

\section{Abstract}

Residential society of tempe craftsmen in Sanan Village Malang is formed from the long residential local wisdom adjustment to globalization, one of them impact on the economy. Initially, residential in this village is only used for family living, but then people started using their residential to produce and sell tempe and tempe chips, and now Sanan Village has become a center of tempe industry. Tempe producing activities for the people of Sanan Village is the local culture Wisdom hereditary enabling change and a reduction in space for dwellings and affect the quality of the residential facade. This study aimed to describe the concept of local wisdom in residential patterns of Sanan villagers that effect on its changes. The method used in this study was descriptive, analytical and interpretive, based on empirical evidence, structuralism, and relations function, form and meaning are used to reveal the concept of local wisdom in Sanan village residential. Data collection is done by taking a photo, video, interview and observation and then analyzed to get an overview and conclusions that can answer problems and achieve the objectives of the study. The results of this study states that the local wisdom of Sanan village directly and indirectly reveal the identity of the new tradition that goes hand in hand with a long tradition. The formation of new local cultural wisdom of the impact of globalization, namely Home Industry as to raise the standard of living of residents of Sanan Village Malang. 


\section{Pendahuluan}

\subsection{Latar Belakang}

Hampir setiap bangunan dalam kurun waktu tertentu akan mengalami perubahan baik langsung maupun tidak langsung, berubah akibat adanya proses adaptasi untuk menghadapi perubahan kebutuhan di tiap-tiap generasi ataupun karena faktor ekonomi. Perubahan ini terjadi karena adanya perubahan peradaban, perubahan spirit zaman dan perubahan dari era lama ke era baru, misalnya dari era pertanian ke era industri, sehingga kemapanan secara ekonomis tentu berubah dan pada akhirnya berujung pada sebuah kebutuhan perubahan yang berimbas pada bangunan. Dalam hubungan ini 2 elemen Budaya perlu diidentifikasi secara cermat. Elemen pertama adalah Inti Budaya yang menolak untuk berubah. Lainnya adalah elemen Budaya yang mampu berubah, tumbuh dengan cepat tetapi perlu didorong untuk mampu menghadapi tantangan dari luar tanpa kehilangan jiwa roh jati dirinya.

Jati diri atau identitas merupakan "jejak" yang ditinggalkan oleh peradaban, bergerak sejalan dengan sejarah dan merupakan sebuah "proses" yang tidak terjadi dengan sendirinya tetapi bertolak dari logika yang dikuti oleh masyarakatnya. Jati diri lahir dan tumbuh dari pengertian terhadap diri sendiri, dan masyarakat lingkungannya (Wiranto, 1999:17).

Secara konsepsual, kearifan lokal dan keunggulan lokal merupakan kebijaksanaan manusia yang bersandar pada filosofi nilai-nilai, etika, caracara dan perilaku yang melembaga secara tradisional. Kearifan lokal adalah nilai yang dianggap baik dan benar sehingga dapat bertahan dalam waktu yang lama dan bahkan melembaga. Kearifankearifan lokal pada dasarnya dapat dipandang sebagai landasan dalam pembentukan jati diri bangsa secara nasional. Kearifan-kearifan lokal itulah yang membuat suatu budaya bangsa memiliki akar (Sartini, 2004:112). Untuk memahami kearifan lokal pada suatu karya arsitektur perlu ditelusuri konsep konsep yang melatar belakangi lahirnya karya tersebut.

Kearifan lokal di Indonesia saat ini menjadi topik bahasan menarik dibicarakan di tengah semakin menipisnya sumber daya alam dan peliknya upaya pemberdayaan masyarakat. Perubahan kehidupan seseorang berdasarkan ide pemikiran dan idealis yang berada disetiap orang karena kebutuhan individual yang kuat. Pengaruh perubahan tersebut berdampak juga pada gaya hidup yang menjadi sebuah tradisi. Berawal dari pemikiran untuk menaikan taraf hidup menjadikan sebuah tradisi lama mengalami perubahan secara perlahan. Dampak globalisasi menyebabkan segala aspek kehidupan terpengaruhi, misalnya sistem ekonomi, budaya dan lingkungan hidup manusia. Hal tersebut menyebabkan kearifan lokal yang berlaku dalam masyarakat mulai terkikis. Masyarakat memiliki tradisi yang dikenal sebagai ada kedaerahan (kearifan lokal) yang merupakan symbol kebangsaan, akan tetapi hampir tidak lagi makna yang berarti di era globalisasi.

Dengan adanya kearifan lokal merupakan pandangan dan pengetahuan tradisional yang menjadi acuan dalam berperilaku dan telah diaplikasikan secara turun-temurun untuk memenuhi kebutuhan dan menjawab permasalahan dalam kehidupan suatu masyarakat. Kearifan lokal memberikan identitas, fungsi dan makna dalam masyarakat menyesuaikan keberadaan penduduk setempat, menjawab problema yang terjadi serta memberikan pengetahuan dan cara bertahan hidup untuk menanggapi lingkungan yang berkembang.

Bertambahnya jumlah keluarga tentu saja akan menambah jumlah kebutuhan dalam memenuhi keperluan anggota keluarga itu sendiri semakin meningkat. Kebutuhan keluarga ini akan terasa ringan terpenuhi jika ada usaha yang mendatangkan income atau penghasilan keluarga untuk menutupi kebutuhan tersebut. Home Industri yang pada umumnya berawal dari usaha keluarga yang 
turun menurun dan pada akhirnya meluas ini secara otomatis dapat bermanfaat menjadi mata pencaharian penduduk kampung di sekitarnya. Kegiatan ekonomi ini biasanya tidak begitu menyita waktu, sehingga memungkinkan pelaku usaha membagi waktunya untuk keluarga dan pekerjaan tetap yang ditekuni.

Banyaknya nilai dan budaya masyarakat yang mengalami perubahan dengan cara meniru atau menerapkannya modernisasi di segala bidang kehidupan, menyebabkan kearifan lokal yang tumbuh dan berkembang di dalam masyarakat menjadi terkikis. Misalnya terjadi perubahan ciri kehidupan masyarakat desa yang tadinya syarat dengan nilai-nilai gotong royong menjadi individual. Selain itu juga banyak yang mengikuti nilainilai budaya luar yang dapat terjadi dehumanisasi yaitu derajat manusia nantinya tidak dihargai karena lebih banyak menggunakan mesin-mesin berteknologi tinggi.

Dengan hadirnya usaha atau pekerjaan baru tidak hanya kearifan lokal yang berubah dari segi ekonomi tetapi juga merubah lingkungannya dan menjadikan identitas warga setempat. Kampung Sanan kota Malang merupakan salah satu Kampung yang warganya bekerja sebagai pengrajin tempe dan sebagian beralih profesi menjadi pengrajin keripik tempe.

\subsection{Tujuan}

Studi ini difokuskan pada upaya mendeskripsikan kearifan lokal Masyarakat Kampung Sanan melalui aktivitas keseharian penduduk setempat dan kegiatan Home Industry. Tujuan utama dari kajian ini adalah untuk mengetahui kearifan budaya lokal pengrajin tempe yang berpengaruh pada perubahan-perubahan huniannya.

\section{Pembahasan}

\subsection{Lokasi Penelitian}

Berdirinya Kampung Sanan diperkirakan sudah lama sekali, dimana keberadaan awal kampung ini (ditandai dengan adanya makam tua (yaitu Makam Buyut Kibah yang(diyakini sebagai pembuka lahan (pertama kali, dan sampai saat ini (masih dihormati oleh penduduk(Kampung Sanan. Pekerjaan utama (penduduk Sanan pada waktu itu (diyakini adalah bertani karena (sampai saat ini masih terdapat sisa-sisa lahan pertanian.

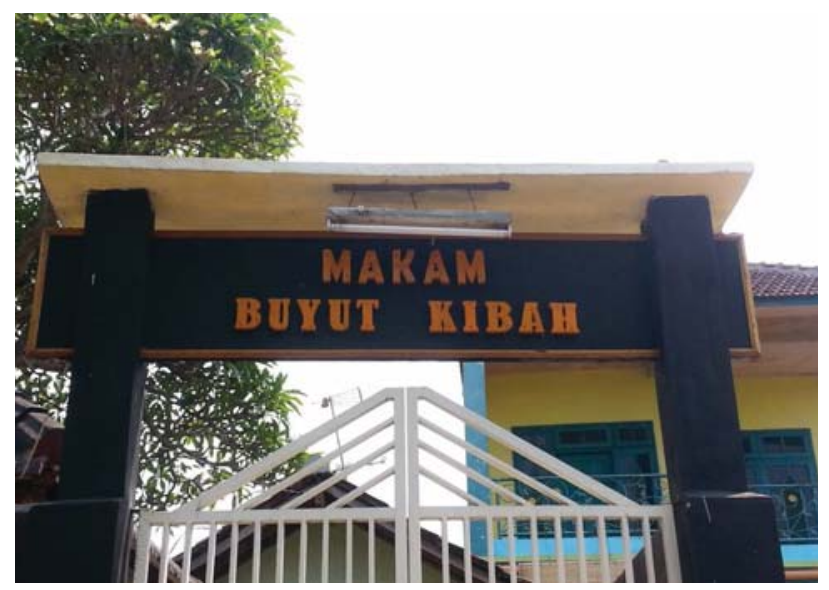

Makam Buyut Kibah pendiri Kampung Sanan (Sumber: Halomalang.com) 
Sebagai penghasil tempe, Kampung Sanan telah dikenal sejak tahun 1900- an (tanggal dan tahun pastinya tidak jelas sama dengan awal berdirinya kampung ini karena tidak ada lagi nara sumber yang bisa menginformasikannya). Sebelum tahun 1970-an warga Kampung Sanan hanya memproduksi tempe saja, yang dipasarkan ke semua pasar di Kota Malang dan Kabupaten Malang. Dalam perkembangannya hingga sekarang, penduduk Kampung Sanan melakukan variasi usaha dengan memproduksi keripik tempe. Ide pembuatan keripik tempe berawal dari banyaknya tempe yang dijual terbuang karena tidak laku. Tempe-tempe sisa tersebut kemudian dicoba untuk dibuat keripik yang ternyata laku dijual di pasaran.

Kampung Sanan yang memiliki luas $\pm 20 \mathrm{Ha}$ ini, terletak di Kota Malang, Kelurahan Purwantoro, Kecamatan Blimbing, yaitu meliputi RW 14 (4 RT), RW 15 (9 RT) dan RW 16 (9 RT) dengan jumlah kepala keluarga seluruhnya \pm 660 keluarga, dan yang tergabung pada koperasi (Primkopti Bangkit Usaha) berjumlah \pm 300 kepala keluarga.

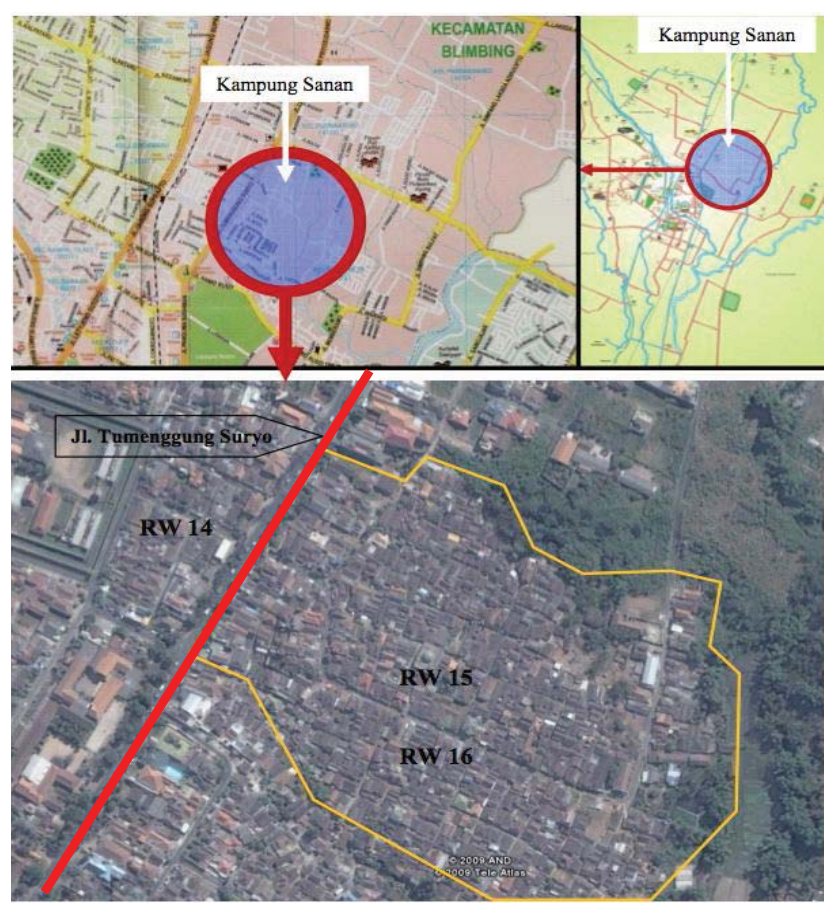

Citra Satelit Kampung Sanan

(Sumber: Google, 2016)
Pada awalnya, Kampung Sanan( baik RW 14, RW 15 dan RW 16 merupakan satu wilayah yang utuh namun sejak dibangunnya Jalan Tumenggung Suryo (dibuat untuk memudahkan jalur transportasi dari Surabaya sampai ke pusat Kota Malang) yang membelah kampung ini sehingga ketiga RW tersebut terpisah dimana RW 14 di sebelah barat dan RW 15 serta RW 16 berada di sebelah timur Jalan Tumenggung Suryo.

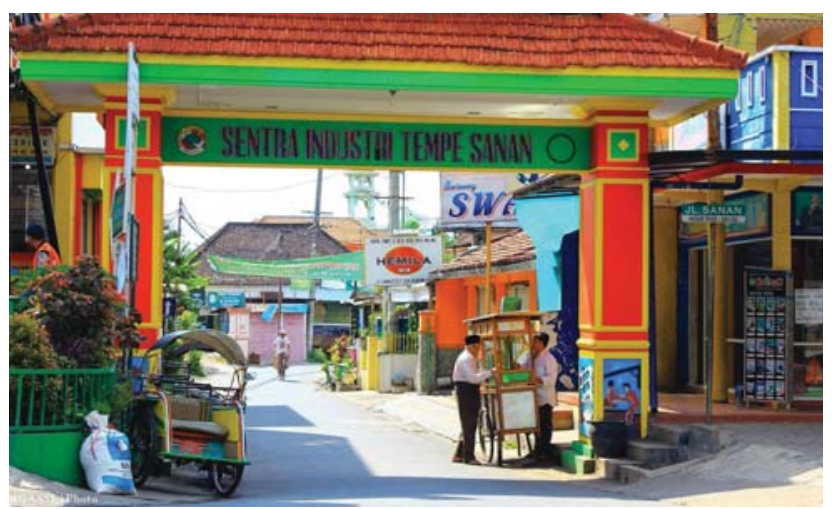

Gerbang masuk Kampung Sanan (Sumber: Google, 2016)

\subsection{Karakteristik Masyarakat Kampung Sanan}

Kekeluargaan dan gotong royong benarbenar terlihat di setiap aktivitas di dalam Kampung Sanan. Baik yang berhubungan dengan usaha kripik tempe yang dijalani maupun kehidupan keluarga sehari-hari. Sebagaimana contohnya adalah tetangga yang saling membantu dan bersikap toleran satu sama lain, mereka tidak akan segan untuk mengulurkan tangan kepada usaha kripik tempe tetangganya walaupun jenis usaha yang dilakukan sebenarnya adalah sama. 


\section{Pengaruh Kearifan Budaya Lokal terhadap Hunian Masyarakat Pengrajin Tempe Di Kampung Sanan Malang}

Rahadian Nugroho

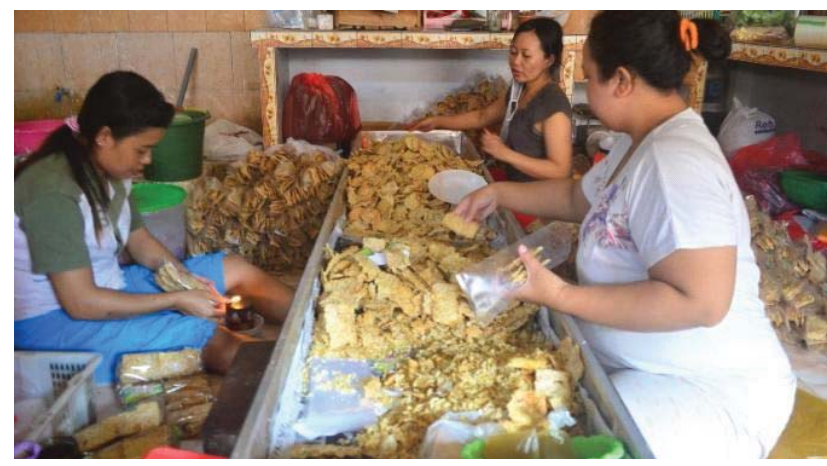

Gotong Royong Mengemas Keripik Tempe (Sumber: Google, 2016)

Karakteristik selanjutnya adalah rasa rendah hati dan terbuka, dengan serta merta, penduduk di Kampung Sanan selalu terbuka menerima pengunjung dengan kerendahan hati yang membuat kesan ramah juga terasa dalam interaksinya. Mungkin dikarenakan pengunjung adalah berkah bagi mereka yang dapat membantu berkembangnya usaha mereka. Dapat dikatakan masyarakat di Sanan terbuka akan masukan dan mereka sadar bahwa perubahan akan memberikan efek bagi kehidupan maupun bisnis mereka.

Tetapi pada kenyataannya, masyarakat memiliki karakteristik yang akan membuat Kampung Sanana akan terus produktif. Kreatif dan Dinamis adalah karakteristik yang dimiliki oleh sebagian besar masyarakatnya; walaupun tingkat pendidikan sebagian besar orang dewasa di Kampung Sanan adalah SMA/SMK dan sederajat, tetapi dikarenakan karakteristik mereka yang terbuka, sehingga informasi dan perkembangan jaman yang dinamis membuat kreatifitas turut berkembang di masyarakatnya. Hal tersebut dibuktikan dengan bagaimana kripik tempe berawal dan berkembang hingga menjadi saat ini. Kampung Sanan yang menjadi pusat pengolahan tempe kedelai sejak bertahun-tahun yang lalu turut berkembang dan bertahan mengikuti perubahan jaman yang dinamis.

Karakteristik lainnya adalah, sikap skeptis yang merupakan pencerminan dari masyarakat di
Kampung Sanan, yang tidak akan percaya akan sesuatu hal jika tidak ada bukti nyata keberhasilan. Diungkapkan beberapa pengusaha kripik tempe, jika pada awal berkembangnya usaha kripik tempe hanya dirintis satu-dua orang saja, tetapi setelah berhasil usaha tersebut mulai menyebar menjadi industri yang dilakukan dalam satu Kampung. Selain itu sikap skeptis juga ditunjukkan kepada pemerintahan dan lembaga-lembaga yang berkaitan dengan pemerintah.

Dan karateristik yang terakhir adalah religius. Religius adalah salah satu karakteristik masyarakat di Kampung Sanan yang dapa mempengaruhi sebagian besar kehidupan di dalamnya. Dengan mayoritas penduduk adalah penganut Islam, nilai-nilai agama juga menjadi pengiring kehidupan dalam masyarakatnya. Menurut keterangan informan, sering diadakan pengajian, ceramah, atau selametan sebagai bentuk rasa syukur kepada Tuhan Yang Maha Esa, di lingkungan Kampung Sanan sendiri. Karakteristik masyarakatnya yang menjujung tinggi nilai-nilai agama dan kekeluargaan juga mempengaruhi bisnis yang ada. Dengan kepercayaan," Rezeki itu di tangan Tuhan, kalau mau berusaha pasti ada jalan." Menjadi pendorong masyarakatnya untuk terus berproduksi.

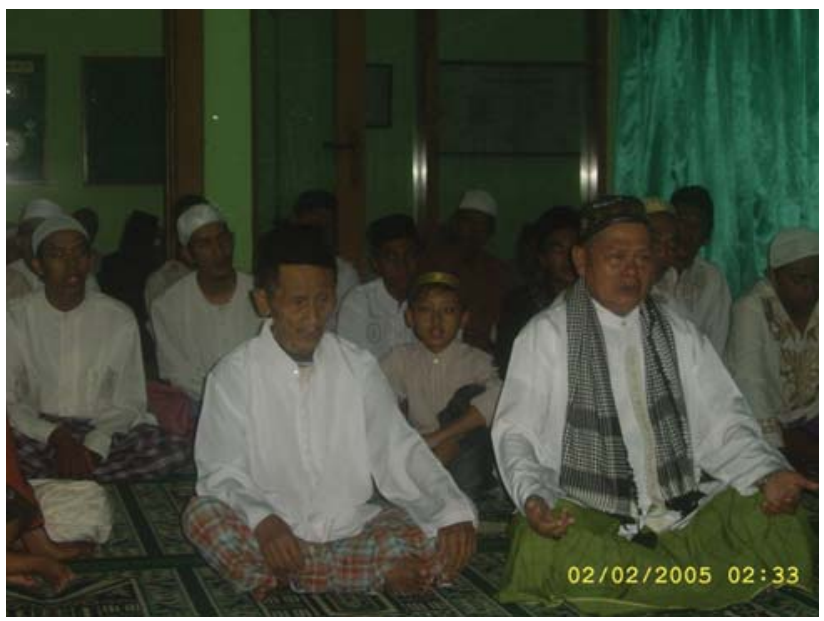

Perayaan Maulid Nabi di Kampung Sanan (Sumber: Google, 2016) 


\subsection{Aktifitas Pengrajin Tempe Sebagai Wujud Kearifan Lokal}

Industri rumah tangga di Kampung Sanan awalnya sekitar tahun 1900an hanya mempunyai satu jenis usaha yang yaitu pembuatan tempe dimana hampir seluruh penduduk Kampung Sanan melakukan pekerjaan ini sehingga produk ini menjadi ciri khas bagi kampung ini. Pada perkembangannya selanjutnya sekitar tahun 1980an sebagian penduduk tidak hanya membuat tempe saja tapi kemudian juga membuat keripik tempe. Produk ini kemudian menjadi salah satu produk unggulan Kota Malang, menjadi pilihan wisatawan untuk dijadikan oleh-oleh.

Proses pembuatan kripik tempe sendiri adalah manifestasi budaya dan kreatifitas yang diciptakan oleh masyarakat yang bermukim di perkampungan Sanan. Telah lama dikenal sebagai produsen tempe terbaik di Malang, maupun di Jawa Timur, tidak serta merta membuat para pengusaa tempe mendapatkan kemudahan dalam melakukan penjualan tempe-tempenya. Sehingga mereka harus memutar otak bagaimana menanggulangi kerugian atas tempe-tempe yang tidak laku tersebut. Seluruh proses pembuatan masih dilakukan dengan cara yang masih manual. Dikarenakan usaha kripik tempe sendiri masih dalam skala industri rumahan, pekerjanya rata-rata tak lebih dari 10 orang, dengan pemilik usaha yang masih turun tangan dalam pembuatan proses produksi. Adapun proses pembuatan tempe adalah sebagai berikut ini:

1. Proses pembuatan tempe diawali dengan menampi kedelai untuk memperoleh biji-biji kedelai yang tua yang kemudian dicuci bersih, lalu direbus sampai setengah matang. Perebusan dilakukan di atas kompor minyak tanah, kayu bakar dan ada pula yang menggunakan kompor gas. Proses ini menimbulkan uap air panas dan asap dari kompor, asap berpotensi mengganggu (polusi) terutama bagi yang menggunakan kayu bakar.
2. Setelah perebusan dirasa cukup, kedelai direndam agar memudahkan pengelupasan sekaligus untuk mencegah timbulnya bakteri pembusuk selama fermentasi. Keesokan harinya, kedelai dikupas kulit arinya dengan menggunakan mesin pemecah/pengupas. Mesin pemecah/pengupas sendiri merupakan hasil karya warga Kampung Sanan yang kemudian di produksi masal dengan merk HAS dan dijual melalui Primkopti, pengguna mesin ini bukan hanya dari warga Kampung Sanan tapi juga dari luar Kota Malang. Setelah kedelai terkelupas dari kulit arinya, sekali lagi dicuci. Pada proses ini dihasilkan limbah padat yaitu kulit ari hasil pengelupasan.

3. Proses ini kemudian dilanjutkan dengan perebusan yang ke dua sampai matang. Hal ini dilakukan untuk membunuh bakteri yang mungkin tumbuh pada saat perendaman. Kedelai yang telah direbus untuk keduakalinya itu kemudian ditiriskan dalam wadah yang terbuat dari anyaman bambu (ebor), proses ini sekaligus ditujukan untuk pendinginan. Tahap perebusan juga menimbulkan efek uap panas dan asap seperti pada tahap satu. Pada tahap ini juga menimbulkan limbah yaitu limbah cair hasil perebusan.

4. Setelah tiris, biji-biji kedelai tersebut kemudian diratakan dalam cetakan yang berupa rak-rak dari bambu ( leleran). Setelah itu ditaburkan ragi. Proses ini adalah proses inti dalam pembuatan tempe. Jumlah ragi yang dipakai tergantung cuaca, jika kondisi udara dingin maka ragi yang diberikan lebih banyak dan sebaliknya.

5. Proses terakhir adalah pemeraman. Biji kedelai yang sudah diragikan dalam rak leleran tadi kemudian ditutup plastik dan diperam semalaman. Keesokkan harinya, tempe yang telah masak kemudian dijual ke pasar-pasar. 


\section{Pengaruh Kearifan Budaya Lokal terhadap Hunian Masyarakat Pengrajin Tempe Di Kampung Sanan Malang}

Rahadian Nugroho
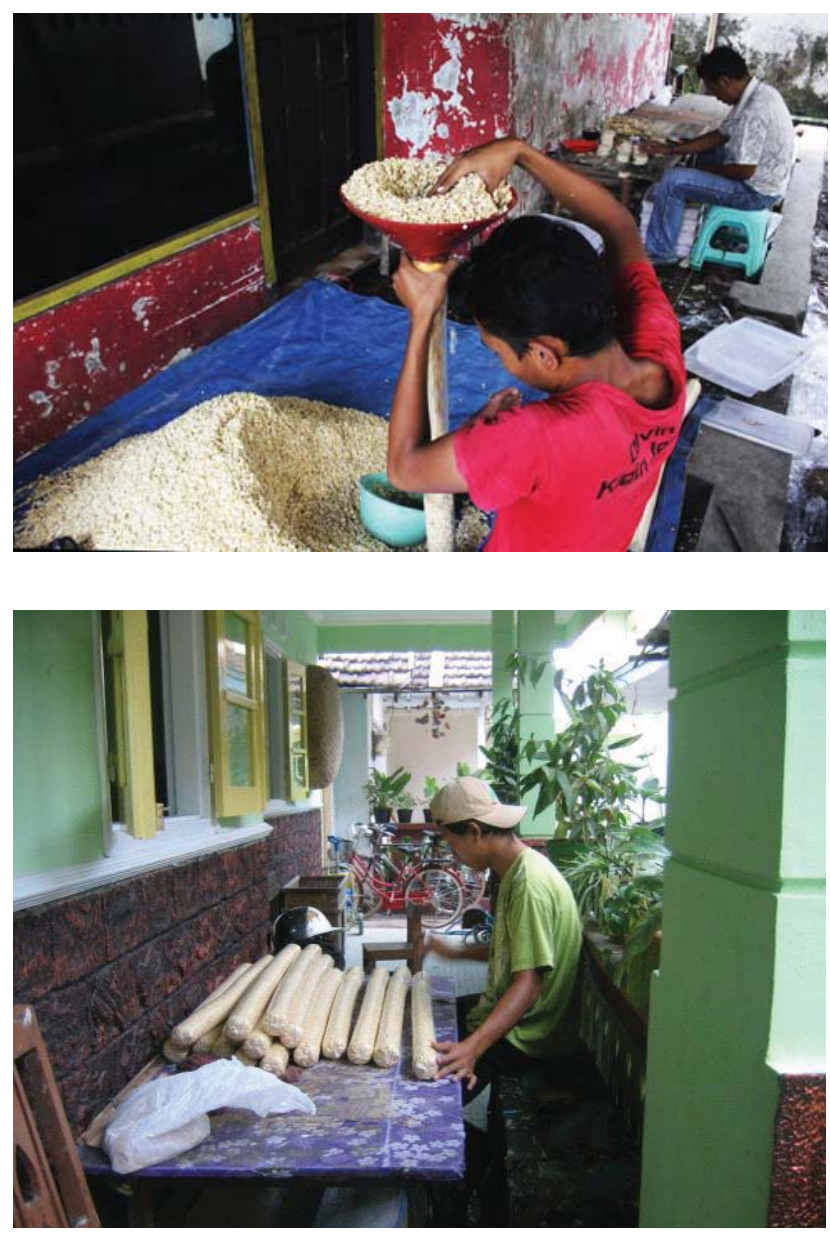

Proses Pembuatan Tempe

(Sumber: Dokumentasi Pribadi, 2016)

Jadi sejak proses awal hingga tempe dipasarkan dalam bentuk jadi, memerlukan waktu kurang lebih tiga hari, namun ada beberapa pengrajin yang menjual dalam bentuk setengah jadi dengan memasukkan kedelai yang telah diragikan ke dalam kantong-kantong plastik dan pembelinya yang akan memeramnya sampai tempe tersebut jadi.

Warga di Kampung Sanan selain membuat tempe juga ada yang berusaha dibidang pembuatan keripik tempe. Keripik tempe merupakan produk yang banyak diminati pembeli tidak hanya dari
Kota Malang tapi juga dari luar Kota Malang bahkan luar negeri sehingga semakin banyak warga yang awalnya hanya membuat tempe kemudian mengembangkan usahanya dengan juga membuat keripik tempe. Tidak hanya memproduksi tapi beberapa hunian juga berfungsi sebagai tempat memasarkannya.

Proses pembuatan keripik tempe adalah sebagai berikut:

1. Tempe mentah dipotong-potong tipis dengan bentuk dan ukuran yang bermacam-macam, ada yang persegi panjang, bujursangkar dan lingkaran tergantung permintaan pasar/ pemesan.

2. Tempe yang telah dipotong-potong tadi kemudian diberi adonan tepung yang telah dicampur dengan bumbu-bumbu penyedap.

3. Tempe kemudian digoreng dengan minyak panas sampai kering.

4. Setelah digoreng, tempe kemudian ditiriskan sampai minyak benar-benar habis, setelah tempe kering dari minyak kemudian adanya yang dibumbui dengan ditaburi penyedap dengan bermacam-macam rasa seperti balado, barbekyu, dan lain-lain. Pemberian bumbu ini sesuai dengan pesanan dan permintaan pasar, tapi ada juga tempe yang tidak dibumbui (original).

5. Keripik tempe kemudian dibungkus pada bungkus plastik yang telah diberi label. Label ini ada yang milik pengrajin sendiri adapula label milik pemesan untuk dijual kembali di tempat lain.

6. Keripik tempe yang telah dibungkus kemudian dimasukkan dalam kotak/dus untuk kemudian siap untuk dipasarkan atau dikirim kepada pemesannya. 

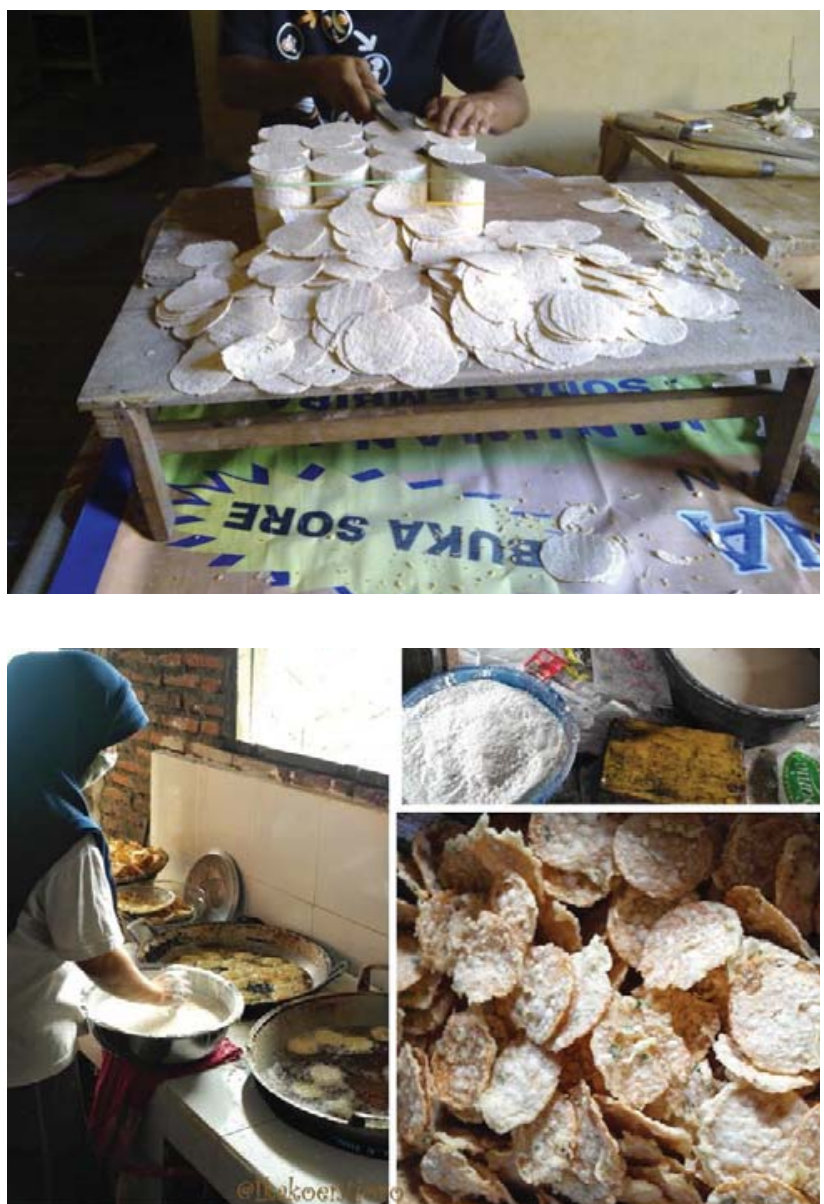

Proses Pembuatan Keripik Tempe (Sumber: Dokumentasi Pribadi, 2016)

\subsection{Perubahan Ruang Hunian Berdasarkan Kearifan Lokal}

\subsubsection{Hunian Pembuat Tempe}

Pada hunian pembuat Tempe tidak banyak terjadi perubahan karena hunian ini dari awal sudah menyediakan ruang khusus untuk bekerja sehingga ruang kerja ini tidak mengganggu ruang domestiknya. Perubahan hanya dilakukan untuk perluasan ruang kerja ke halaman samping rumah, tanpa membangun atau menambahkan dinding.
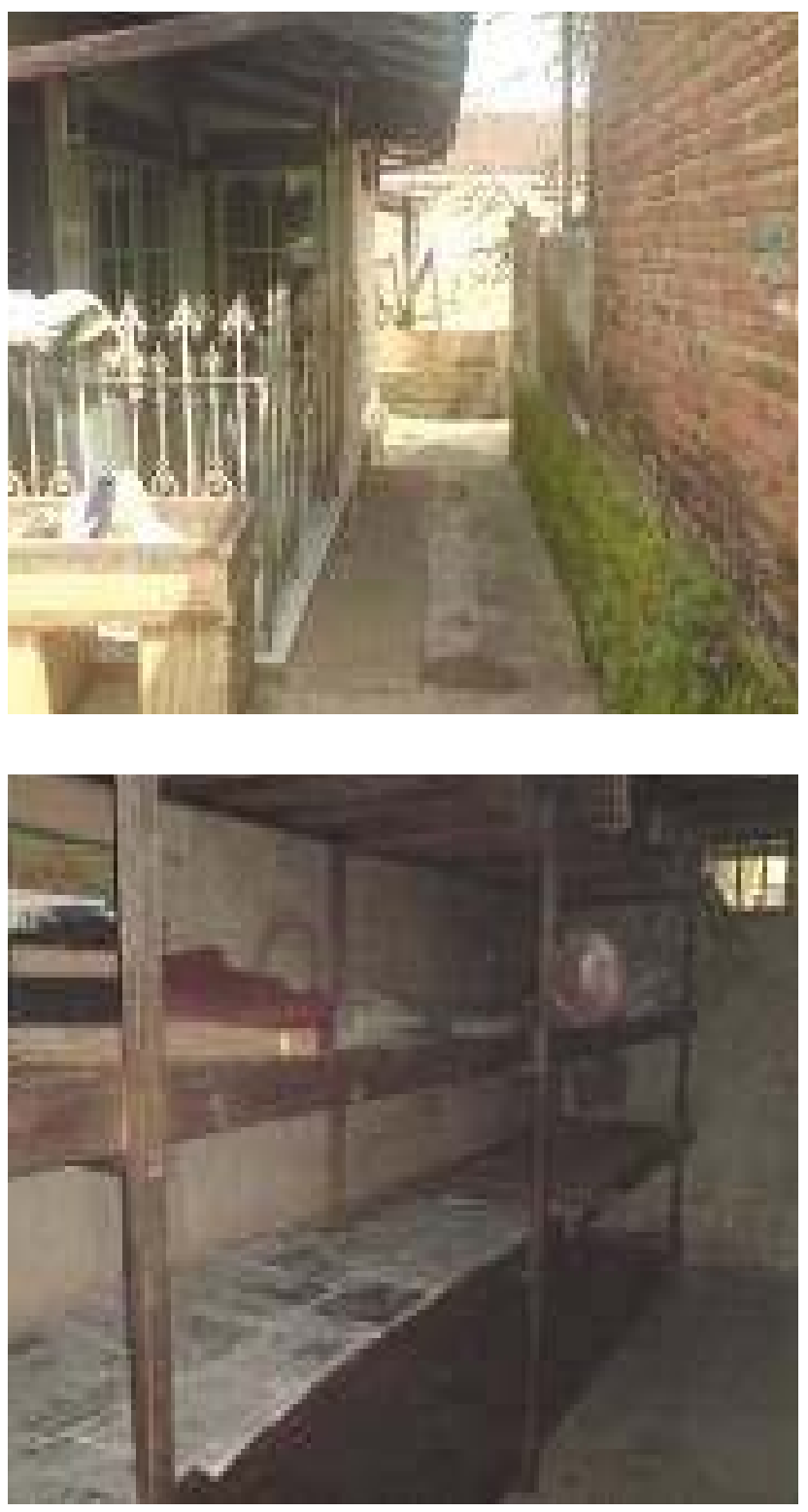

Fasade dan ruang Kerja Hunian Pembuat Tempe (Sumber: Dokumentasi Pribadi, 2016) 

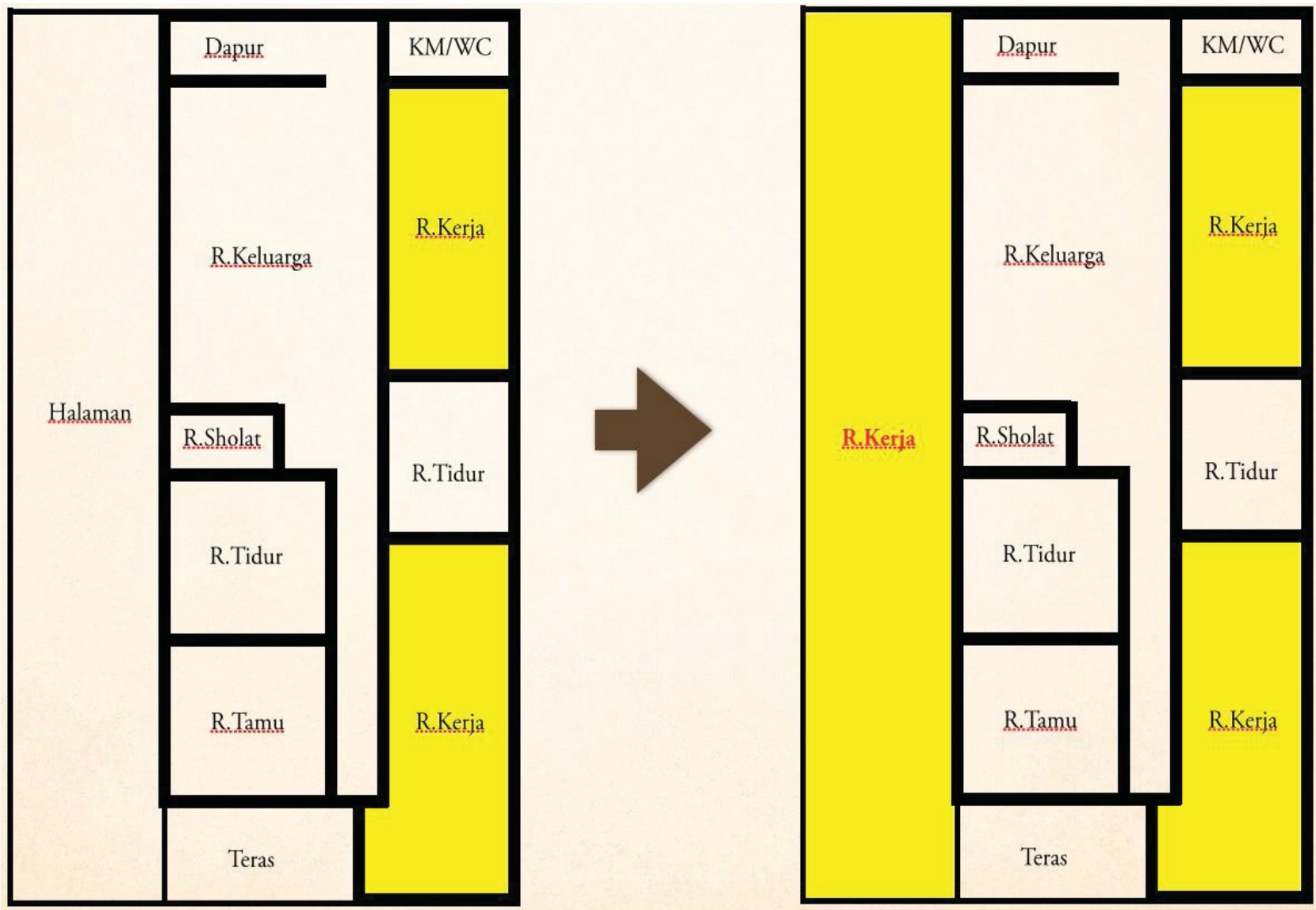

$=$ Ruang Domestik

$=$ Ruang Kerja

$=$ Ruang Domestik bercampur dengan ruang Kerja

\subsubsection{Hunian Pembuat Keripik Tempe}

Pada hunian pembuat Keripik Tempe perubahan yang terjadi adalah perubahan fungsi ruang tidur sebagai ruang domestik menjadi dapur yang merupakan ruang domestik juga kemudian juga dimanfaatkan sebagai ruang kerja jadi ada penambahan ruang bersama yang dipakai bersama antara ruang domestik dengan ruang kerja. 
LOCAL WISDOM, Vol. 9 No. 2 Juli 2017

Local Wisdom Scientific Online Journal

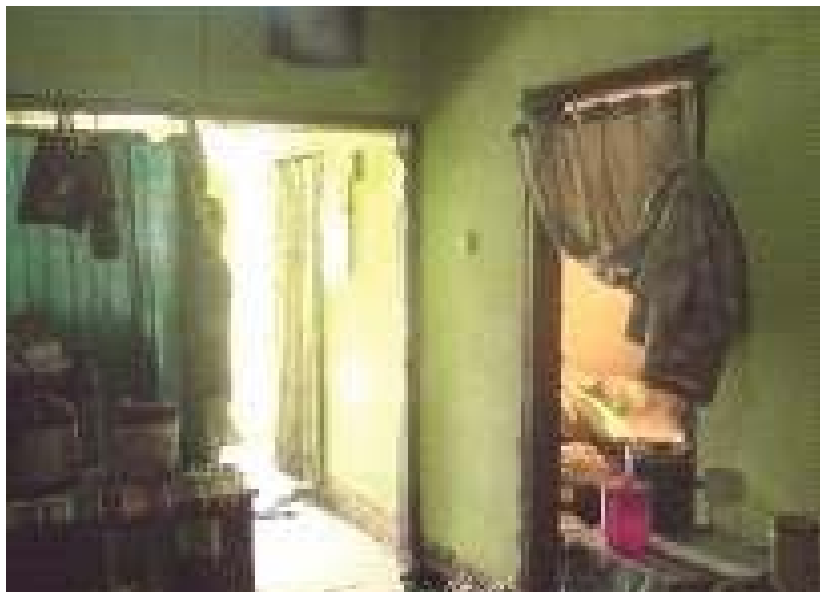

Fasade dan ruang Kerja Hunian Pembuat Keripik Tempe

(Sumber: Dokumentasi Pribadi, 2016)
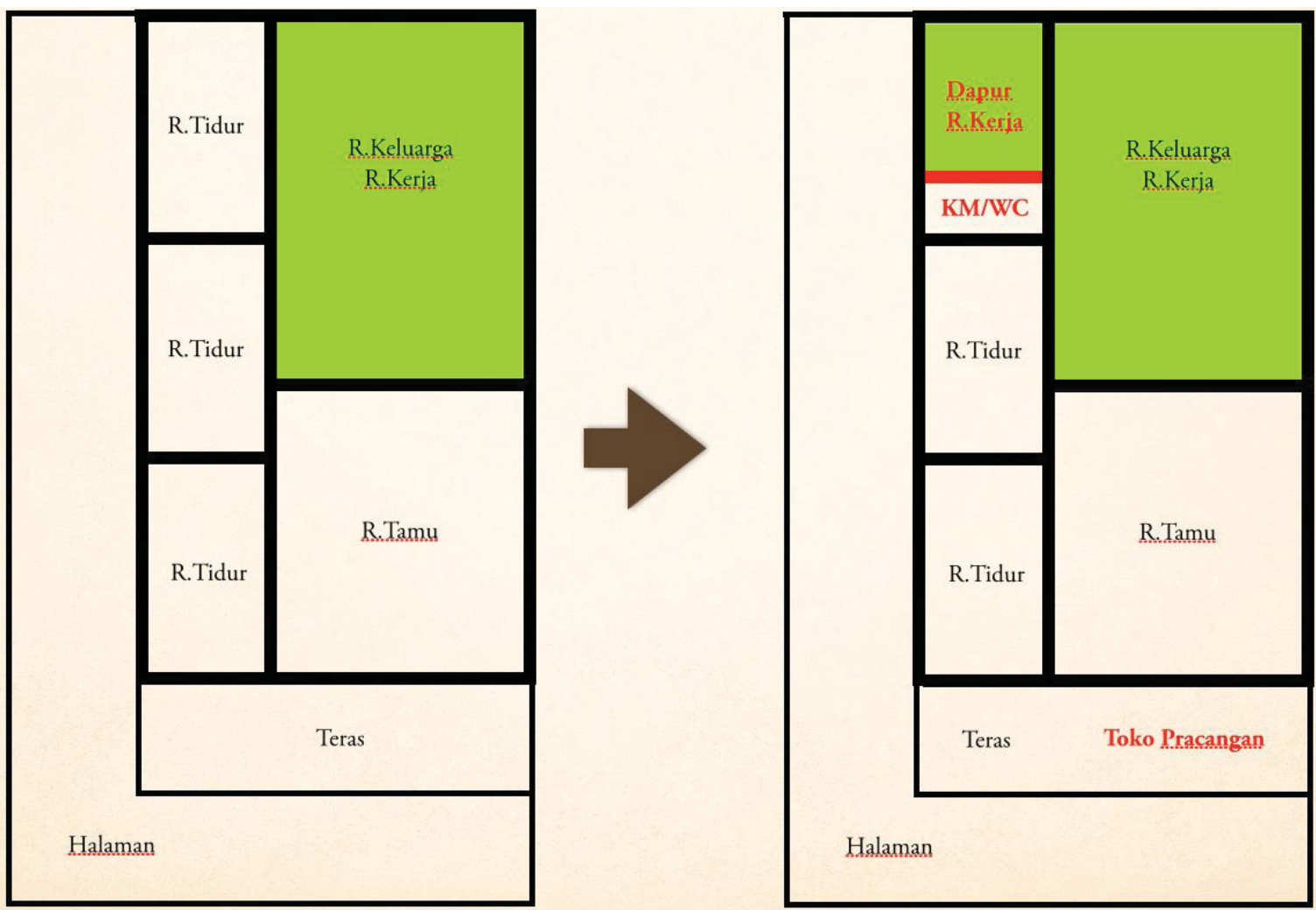

Denah Perubahan Ruang Hunian Pembuat Keripik Tempe

(Sumber: Dokumentasi Pribadi, 2016) 


\subsubsection{Hunian Pembuat Tempe dan Keripik Tempe}

Pada hunian Pembuat Tempe dan Keripik Tempe mengalami perubahan dengan penambahan

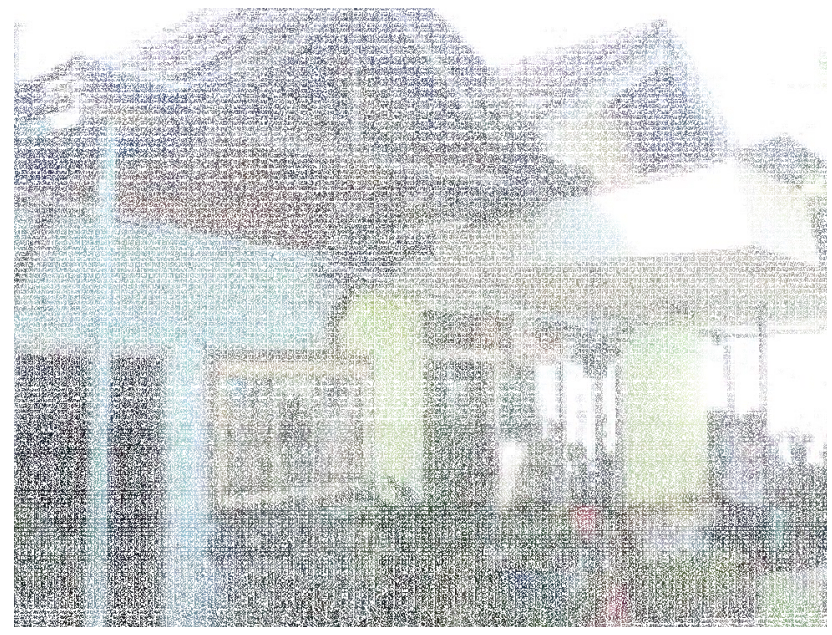

ruang ke samping untuk usaha dari yang awalnya merupakan halaman.

Fasade dan ruang Kerja Hunian Pembuat Tempe dan Keripik Tempe

(Sumber: Dokumentasi Pribadi, 2016)
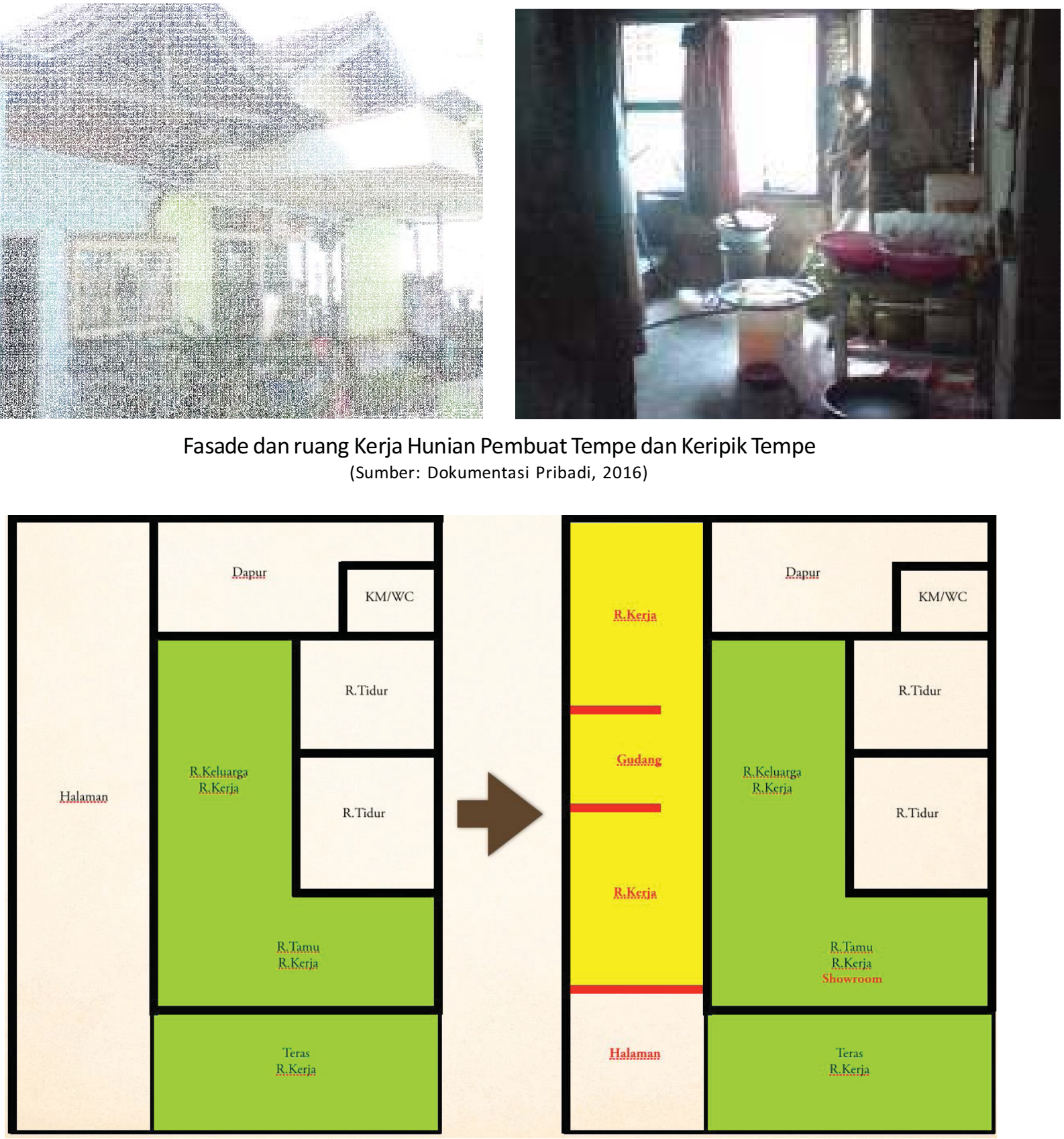

Denah Perubahan Ruang Hunian Pembuat Tempe dan Keripik Tempe (Sumber: Dokumentasi Pribadi, 2016) 
2.4.4 Hunian Pembuat Tempe, Keripik Tempe, dan Membuka Showroom

Pada hunian Pembuat Tempe, Keripik Tempe, dan Membuka Showroom perubahan yang
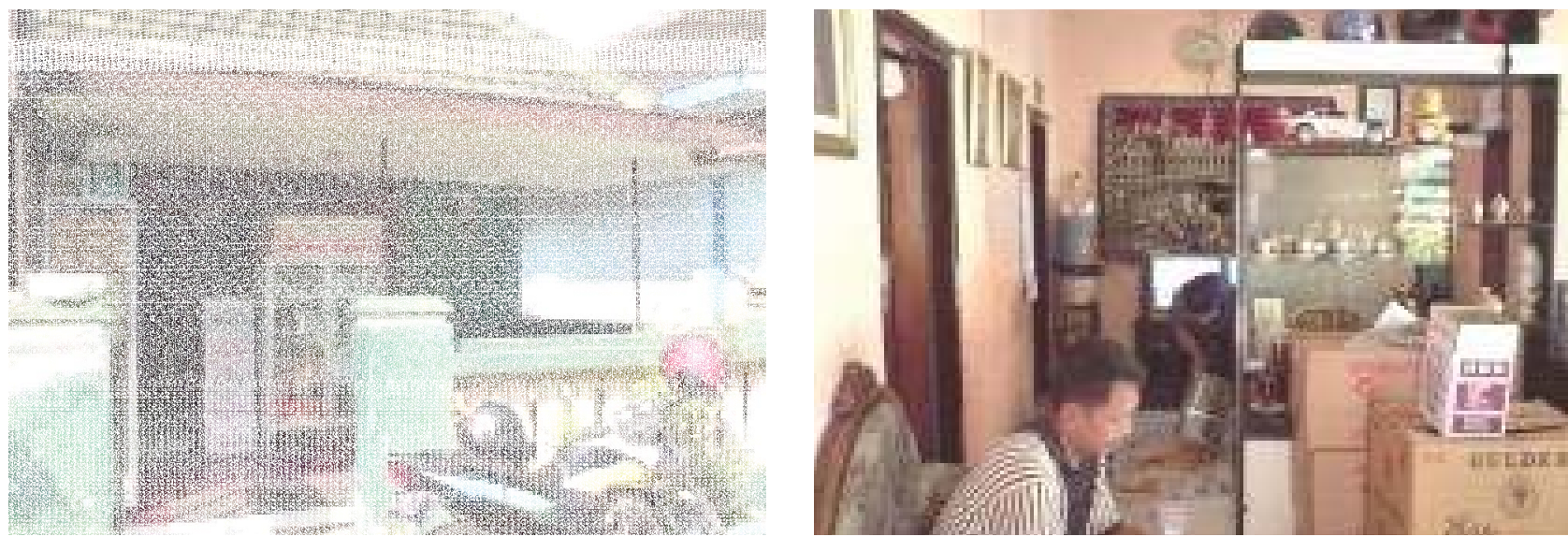

Fasade dan ruang Kerja Hunian Pembuat Tempe, Keripik Tempe dan Membuka Showroom (Sumber: Dokumentasi Pribadi, 2016)
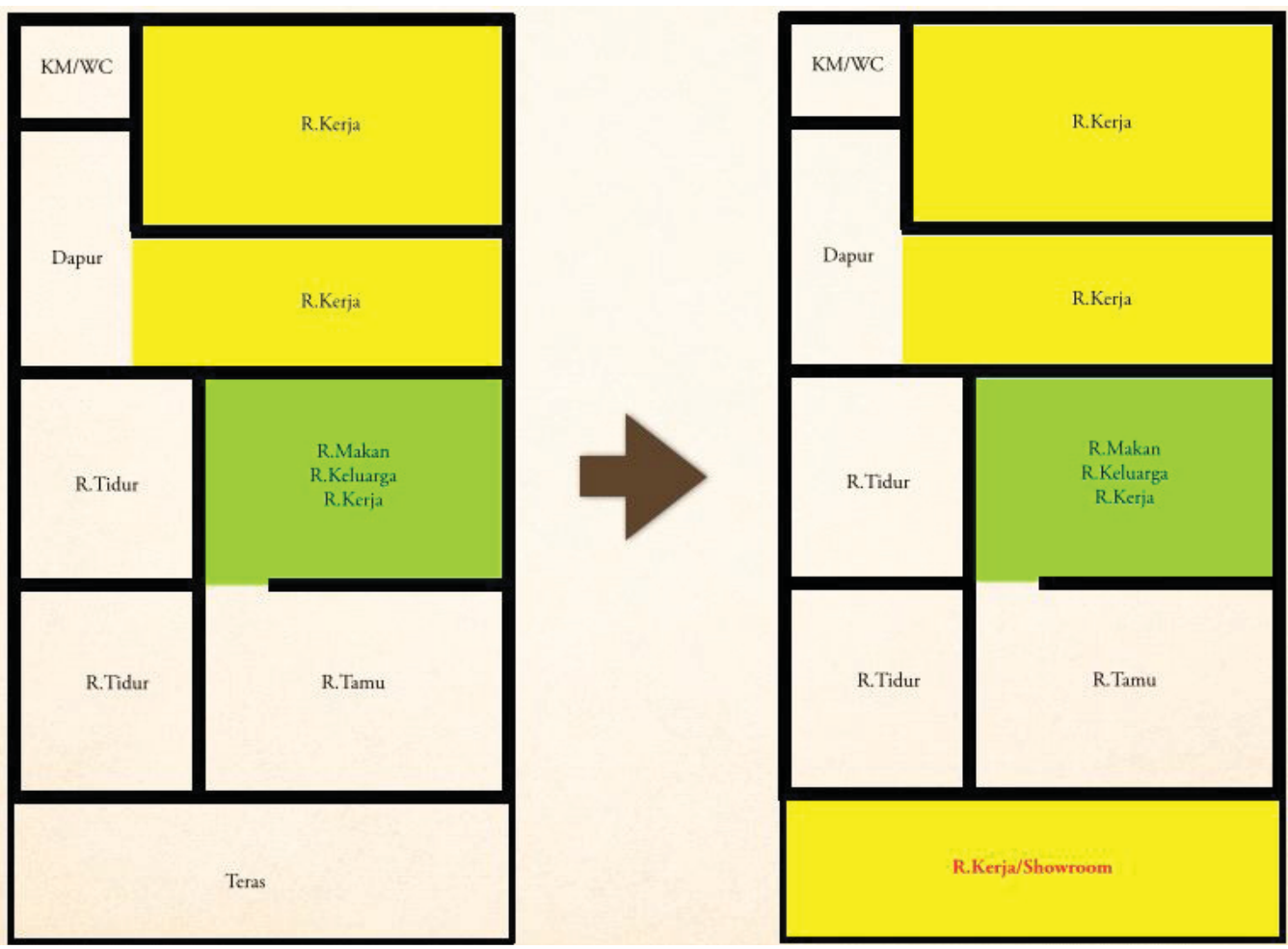

Denah Perubahan Ruang Hunian Pembuat Tempe, Keripik Tempe, dan Membuka Showroom (Sumber: Dokumentasi Pribadi, 2016) 


\section{Pengaruh Kearifan Budaya Lokal terhadap Hunian Masyarakat Pengrajin Tempe Di Kampung Sanan Malang}

Rahadian Nugroho

\section{Kesimpulan}

Kearifan lokal dan perubahan hunian yang terbentuk di Kampung Sanan merupakan efek dari penyesuaian lingkungan hidup, aktivitas, kebiasaan sehari-hari terhadap dampak pemikiran warga untuk meningkatkan ekonomi dan tanpa disadari menjadi sebuah tradisi yang melekat menjadi bagian keseharian warga. Kearifan lokal yang terdapat pada Kampung Sanan lebih terlihat secara nyata (berwujud) dan tidak kasat mata.

Adanya pembagian kategori berdasarkan perubahan lebih memperjelas pola perubahan dan pemanfaatan ruangnya. Usaha yang dilakukan penghuni yaitu housing adjustment dapat dilihat secara spasial dan secara fisik. Secara spasial susunan ruang didalam bangunan hunian di Kampung Sanan bertambah majemuk, ada kecenderungan penambahan maupun perluasan ruang, terdapat perubahan fungsi pada ruang hunian, dan peningkatan kualitas ruangan. Secara fisik pada tatanan ruang bangunan hunian telah terjadi penambahan dan pengurangan dinding ruang dalam hunian sebagai bagian untuk memperluas atau mengubah fungsi ruang.

Perubahan pada hunian bukan dilakukan untuk mendapatkan kenyamanan bertempat tinggal, bukan pula untuk mengembalikan fungsi domestik yang dimanfaatkan bersama untuk produksi pada fungsi domestik yang sebenarnya tapi perubahan dilakukan untuk mengembangkan usahanya industrinya. Pengembangan usaha tersebut meliputi penambahan kapasitas produksi, perubahan jenis usaha dari membuat tempe menjadi keripik tempe dan penambahan jenis usaha dari yang awalnya membuat tempe menambah usaha juga membuat keripik tempe dan membuka toko/showroom. Apa yang telah penghuni di Kampung Sanan lakukan terhadap huniannya saat ini merupakan merupakan tindakan terbaik yang mereka lakukan untuk memenuhi keinginan mereka, sehingga mereka dapat merasakan bahwa hunian mereka saat ini sudah tepat dan memberikan manfaat sesuai yang mereka inginkan.

\section{Referensi}

Habraken, N. J. (1998), The Structure of The Ordinary : Form and Control in the Built Environment, The MIT Press, Massachusetts.

Turner, J. F. C. (1972), Freedom to Build, Dweller Control of Housing Process, The Mac million Co, New York.

Shurtleff, W., and Aoyagi, A. 2007. History of fermented soymilk and its products. Soy Info Center Layafette, California.

Sartini, 2004. Menggali Kearifan Lokal Nusantara Sebagai Kajian Filsafat. Jurnal Filsafat. Jilid 37, Nomor 2 hal. 111-120. http://dgi-indonesia.com/ wp-content [Diakses 8 September 2001.

Wiranto. 1999. Arsitektur Vernakular Indonesia. Dimensi Teknik Arsitektur. Volume 27, Nomor 2: 15-20. 